\title{
Sentimental Objects: Nostalgia and the Child in Cinema of the Spanish Memory Boom
}

El presente artículo indaga en cómo dos películas del llamado "boom de la memoria histórica" española representan a sus protagonistas infantiles partiendo de cierta "ansiedad de influencia" relacionada con la película antecesora El espíritu de la colmena (Erice, 1973). Argumenta que, a pesar de cierta relación intertextual, estas dos películas más recientes se diferencian de su predecesora en términos de su representación de la infancia, haciendo uso del niño como una herramienta de didactismo y nostalgia; en el proceso, ofrecen una imagen del niño que se instrumentaliza como objeto, en vez de realizarse como sujeto.

Palabras claves: el niño en el cine, el "boom" de la memoria, nostalgia, cine histórico, guerra civil española

This article explores how two films from the so-called Spanish "memory boom" represent their child protagonists via a certain "anxiety of influence" in relation to their cinematic forebear El espíritu de la colmena (Erice, 1973). It argues that, despite their intertextual connection, these two more recent films differ from Erice's in terms of their representation of childhood, making use of the child as an instrument of didacticism and nostalgia. In so doing, they offer an image of the child instrumentalized as object, rather than fully realized as subject.

Keywords: child in cinema, "memory boom," nostalgia, heritage cinema, Spanish civil war

Given the seemingly ubiquitous presence of child characters in films set during Spain's Civil War (1936-1939) and ensuing Franco dictatorship (1939-I975), it is not remotely surprising that in recent years the child has become something of a "hot topic" in Spanish cultural and film studies. ${ }^{\mathrm{I}}$ Perhaps more surprising is that it took this long. The child's appeal in films dealing with civil conflict or repressive regimes is not unique to the Spanish case, though this nation's cinema is one of the most rich and nuanced in its showcasing of child protagonists against the backdrop of war and dictatorship. ${ }^{2}$ Within this genre, no film has received as much 
attention as Víctor Erice's 1973 El espíritu de la colmena. Beloved by scholars and critics, and one of the most internationally well-known examples of Spanish auteur filmmaking, Erice's iconic film casts a long shadow over child-centered and historical cinema of the last decades in Spain. Although frequently examined alongside other films by key directors of the New Spanish Cinema such as José Luis Borau or Carlos Saura who came of age under the dictatorship (memorably classified by Marsha Kinder as the "Children of Franco"), more than any other film from the period, El espíritu de la colmena seems to haunt subsequent childcentered films that approach Spain's turbulent political past.

This is especially the case in cinema emerging from the so-called "Memory Boom" of the late i990s and first decade of the 2000 s featuring child characters. ${ }^{3}$ These historical films - marked by their meticulous heritage-style reconstruction of period detail as well as their frequent recourse to sentimentality - are strikingly different from their I970s auteur predecessors, which are notably more sparse in aesthetic, style, dialogue, and mise-en-scène. This divide exists to a certain extent between I970s auteur cinema and I990s/2000s mass-market historical cinema more broadly, but for the purposes of the present analysis I am especially interested in the contrasts between child-protagonized films from both periods, especially as concerns a recurring theme in criticism: what we might call an "anxiety of influence" wielded by El espíritu de la colmena over subsequent films, in this case José Luis Cuerda's 1999 La lengua de las mariposas and Imanol Uribe's 2002 El viaje de Carol. ${ }^{4}$ Concretely, this manifests in a general critical consensus that these two key films of the Memory Boom are poor sentimental imitations of the influential earlier child-focused films made under the dictatorship or in its immediate aftermath, which in contrast tend to be opaque, slow, non-linear, metaphorical, allegorical, and generally more "difficult" than their later counterparts. ${ }^{5}$ This critical position holds that the recent heritage-style child-protagonist films from the democratic period are much more sentimentalized, superficial, or somehow "easy" in their modes of representation of the past specifically in contrast to their earlier childcentered counterparts made under the Franco dictatorship. However, in noting the indebtedness of later sentimental films, and especially the two I examine here, to their foundational intertext El espíritu de la colmena, most of these comparative critiques only address the child-centered aspect of the films as one of several features evincing their copycat nature, without interrogating in detail how it is that the films differ in their representations of childhood itself. ${ }^{6}$

Analyzing how these films make use of their child protagonists is vital, I believe, to understanding both their engagement with Spain's historical 
past and with the figure of the child. In what follows I am interested in theorizing what it is about the child's presence in these two moments in Spanish cinema that leads to such contrasting representations of the child as subject, and how the child is deployed within the aesthetic and political frameworks of cinema in both periods. I focus on two representative examples from the first years of the Memory Boom cinema, La lengua de las mariposas and El viaje de Carol, exploring both in formal and thematic terms why it is that these more recent films do not do what El espíritu de la colmena does, what they do instead, and what they do in particular to or with the child. I would like to propose that these two contemporary films differ from their earlier counterpart in several important ways that are often collapsed under the broad umbrella of "sentimentality" or "nostalgia," but which merit further scrutiny, particularly regarding the films' representation of the child figure. I argue that, in contrast to the ambiguity and complexity that marked the earlier film's representation of the past and the child, La lengua de las mariposas and El viaje de Carol deploy the child as a tool for nostalgic ends and didactic purposes (which partly accounts for their enduring popularity as pedagogical material in the Spanish language and culture classroom). In such a framing, however, these two films offer an image of the child instrumentalized as object rather than invested with autonomy as subject, resulting in a more surface-level engagement with both history and childhood.

THE INTERTEXTUAL CHILD

The centrality of childhood to Spanish cinema is longstanding, particularly as concerns filmic representations of the nation's devastating Civil War and repressive Franco dictatorship. In part as a result of the recently much-critiqued Transition to Democracy (roughly 1975-1982), which opted for consensus that smoothed over past injustices, the nation's contested and traumatic past continues to be debated in the public, political, and legal spheres, simultaneously being worked through (or perhaps fossilized) in cultural production. This was especially the case in the unprecedented surge in novels, films, and television programs engaging with Spain's violent past of civil conflict and authoritarianism, during the Memory Boom of the r 990 os and especially first decade of the 2000 s. Films dealing with these historical events have remained popular well into the twenty-first century, and in Spanish cinema both emerging from and retrospectively depicting these violent and historically contested periods, we find a proliferation of child protagonists and films highlighting the child's perspective, in genres ranging from melodrama to horror.? There are many reasons this is the case: skirting Francoist censorship through allegory and the child's supposedly depoliticized gaze; addressing the 
postmemorial concerns of directors who grew up in the war and postwar periods and incorporate autobiographical components in their films; or imagining childhood as a universalizing category of experience that might improve a film's market share abroad, to name just a few. These several motivations have resulted in a lengthy catalog of films belonging to what Sarah Wright has aptly termed the "child and the Spanish Civil War genre," which reached a saturation point during the Memory Boom years (I24). ${ }^{8}$ As she notes in The Child in Spanish Cinema, "The child might be seen as a lingua franca which allows directors to present an attractive and comprehensible face to investigations of the Spanish past (both for Spanish audiences and internationally)" (93). Yet, as Wright's reading of the child figure in a broad genre she terms "art-house horror" attests, many if not all of the child-centered films of the last decades hearken back on some level to Erice's pathbreaking 1973 El espíritu de la colmena, whether through visual echoes, thematic similarity, or even direct citation. This earlier film, made at the tail end of the dictatorship and set one year after the Civil War's conclusion, provides an abstract meditation on childhood, loss, trauma, and the history of violence, following protagonist Ana (Ana Torrent) as she attempts to make sense of fantasy and reality, present and past, and searches for a spirit inspired by Frankenstein's monster after viewing the I93I James Whale film. El espíritu de la colmena's lasting appeal inside and outside Spain has earned it privileged status as a prestige art film. It is also one of the few Spanish films (and often the only one) to be considered in broader conversations about the child in cinema, analyzed in detail in Vicky Lebeau's Childhood and Cinema as well as Karen Lury's The Child in Film: Tears, Fears and Fairy Tales. As Wright notes, the film "is paradigmatic of the ways that Spanish films can engage with the figure of the child," and Torrent's performance in it echoes through much of Spain's subsequent child-centered cinema (157).

Of the many "child and the Spanish Civil War" films that could be explored as inheritors of El espíritu de la colmena, the two I have selected for analysis here are in my view emblematic of a particular sentimental, nostalgic brand of filmic childhood that extends beyond Spain's borders but achieved iconic status in its national cinema with these two films. The better-known La lengua de las mariposas was a box office success in Spain (the fourth highest-grossing film of I999, after its release in October of that year), found wide distribution internationally, and has become a mainstay on the Spanish-language pedagogy circuit. ${ }^{9}$ Based on three interwoven short stories from Manuel Rivas's 1996 collection Qué me queres, amor? ("A lingua das bolboretas," "Un saxo na néboa" and "Carmiña") it episodically relates eight-year-old Moncho's (Manuel Lozano) initiation into education and discovery of the taboos of sex and violence, all on the eve of the Civil 
War in rural Galicia. The political tensions gripping the nation in the troubled months leading up to the July 1936 coup attempt are writ small in the village where the action is set, primarily revolving around the villagers' varying reactions to the liberally-inclined and Machado-inspired teacher Don Gregorio (Fernando Fernán-Gómez). El viaje de Carol, while less wildly successful than this first film, nonetheless received wide distribution abroad (evidenced, for example, by its availability on Amazon streaming video and continued re-release on DVD). The film narrates the journey of twelve-year-old tomboy Carol (Clara Lago) with her mother from the United States - where Carol has grown up with her Spanish mother and American father - to the mother's native town in Cantabria, during the last year of the war. The mother, it is soon revealed, is suffering from a terminal illness and dies not long after arrival; meanwhile, the father is a pilot off fighting on the Republican side in the International Brigades. In a similar fashion to La lengua de las mariposas, the events of the Civil War unfold in the microcosm of the small provincial town, which is complete with stock characters and predictable or whimsical events: the conservative aristocratic family backing the Rebel side, the caricatured Falangist bad-guy with requisite moustache, the wise and unconventional middle-aged single woman who backs the Republic, menacing graffiti and reprisals carried out by local thugs, and the unlikely birthday surprise from Carol's father who pops by in his fighter plane to drop her a gift. ${ }^{\text {IO }}$

Both films make use of the "child and the Spanish Civil War" genre in rather heavy-handed fashion, due in no small part to their filtering of the events of the war or its lead-up through the child protagonist's perspective. Although scholarly and critical treatments of the films are at times celebratory, criticism of both frequently addresses or problematizes their status as glossy heritage cinema. To give just a few representative examples among many, Sally Faulkner notes of El viaje de Carol that its deployment of the [child's perspective] "leads to comprehension and comforting simplification that ends up spiraling off into a sentimental treatment of childhood that has little to do with its Civil War context" (2545). Wright likewise asserts that "despite depicting the 'paseos' [extrajudicial killings], Civil Guard brutality and the killing of a child, [the film] nevertheless manages to dwell lovingly on period detail...in a way which makes the film seem like nothing other than a holiday romance for the protagonist" (IO8). La lengua de las mariposas fares similarly. Paul Julian Smith writes in his review in Sight and Sound that "This pleasing aesthetic gloss ... is precisely what makes Butterfly's Tongue so problematic ... few non-Spanish viewers are likely to guess that this was the poorest of Spanish regions. Poverty has rarely seemed so picturesque" (39-40). Although in his opinion the film resists falling into "el sentimentalismo 
blando ni en el happy end hollywoodiense," José F. Colmeiro nonetheless notes that the film "estéticamente camina por vías ya conocidas e identificadas con un modo de representación característico - cuidada producción, cinematografía exquisita, la rústica y utópica ambientación pastoral, la mirada de la inocencia infantil - en la tradición de El espíritu de la colmena, El Sur, Los años oscuros, Secretos del corazón, o incluso Belle Époque" (193).

I will return to the question of heritage aesthetics below, but first I would like to point out another recurring theme that Colmeiro's assessment indicates: mention of the intertextual presence of Erice's 1973 film in more recent offerings. These two Memory Boom films' debt to $E l$ espíritu de la colmena is frequently pointed out by critics, who trace several referential connections to the foundational earlier film in both Cuerda's and Uribe's works. Smith notes in the same Sight and Sound review that La lengua de las mariposas is citational of El espíritu de la colmena in its torchlit search for a missing Moncho and presence of actor Fernando FernánGómez, concluding that "Unfortunately, such comparisons aren't to Butterfly's Tongue's credit" (39-40). Faulkner, for her part, cites Erice's film as a "privileged intertext" for El viaje de Carol, contrasting the two films' endings as a means of underscoring the latter's rosy-colored view of politics: “...while The Spirit of the Beehive ends with Ana's enigmatic confrontation of a monstrous post-war Spain, Carol takes an improbably jolly taxi-ride through a supposedly war-torn country to escape to a sunny future in America, to which, she is promised, her imprisoned father will return and her grandfather will soon visit" $(253 ; 255)$. Colmeiro, though slightly less critical than his counterparts, nonetheless notes as cited previously that La lengua de las mariposas's privileging of a child's perspective, rural setting and art-house cinematography directly tie it to earlier films including El espíritu de la colmena. ${ }^{\mathrm{II}}$ It seems, then, that these films are not only indebted to Erice's but that their directors also to some degree consciously and intentionally position them as its heirs, in both thematic or plot-based elements and the presence of a child focalizer. Such a positioning serves not only to elevate the films' status by association with their prestigious forebear but also to signal that they too are Doing Something Important with the child and with Spain's turbulent recent history, enshrining them within the "child and the Spanish Civil War" genre. But what it is that these newer films are doing and why do so many critics seem to concur that it does not measure up to earlier films by directors like Erice? 
THE INSTRUMENTAL CHILD

To begin with, in terms of their content, these two later films approach the child and the past in a radically different way than earlier counterparts like El espíritu de la colmena. In part for logistical or practical reasons - chiefly, censorship - films made under Francoism simply could not confront the Civil War in the head-on fashion that contemporary ones can. But it is not merely the representation of the political past that differentiates the two approaches; it is also the way in which the newer films relate the child to the past (and to the spectator) that is of interest here. While in Erice's film the child figure is not an active participant in the political sphere by any means, details of the film's plot and mise-en-scène nonetheless link her intimately to it, gesturing toward the devastation of the recent Civil War, which is only obliquely addressed. Not only does the family unit at the film's center bear the scars of the conflict, so do the spaces in which the child Ana seeks the "spirit" of its title, finding instead a fugitive from the defeated Republican side sheltering in an abandoned hut in the middle of a desolate plain [Figures I and 2]. The contemporary films, to a much more explicit degree, highlight the child's witnessing of certain aspects of the conflict: Carol discovering threatening graffiti on her grandfather's house or learning about summary executions; Moncho overhearing political arguments between his parents or observing the clashes between the local priest, brutish cacique and the liberal schoolteacher as tensions mount in the days leading up to the military uprising.

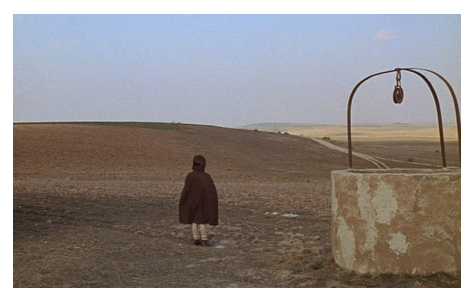

Figure I

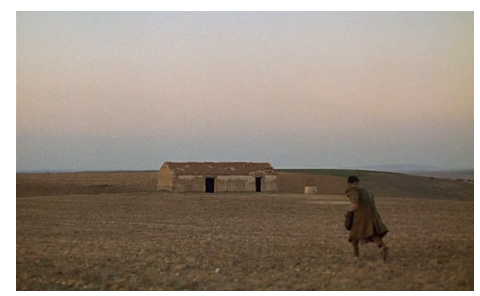

Figure 2 
The latter films not only ahistorically depict the past in implausibly charming style, they also depoliticize their child characters. In both films, the children are largely cast as above, outside, or beyond the political to such a degree that their relationships and experiences radically transcend boundaries of social class and political affiliation. This is most notably the case in El viaje de Carol, where the facile representation of American-raised Carol's liberal and cosmopolitan tendencies (and tomboy identity) marks her as an anomaly in the conservative town. The film's opening sequence, for example, depicts an appalled priest and altar boy gaping at Carol and her mother (María Barranco) on the train to the village - both wearing pants and the mother smoking as a means of telegraphing their modernidad. More unlikely still is tomboy rebel Carol's admiration of her cousin Blanca (Luna McGill), despite her strict and normative upbringing in a right-wing family, or Carol's friendship and budding romance with Tomiche (Juan José Ballesta) across radical divisions of class. ${ }^{\mathrm{I2}}$ By the same token, the films depoliticize the events of the war by making them yet another episode in the children's nostalgic coming-of-age stories, alongside the sentimentalized portrayal of their experiences of young love, first kisses, and whimsical mischief in a pastoral setting [Figure 3]..$^{13}$

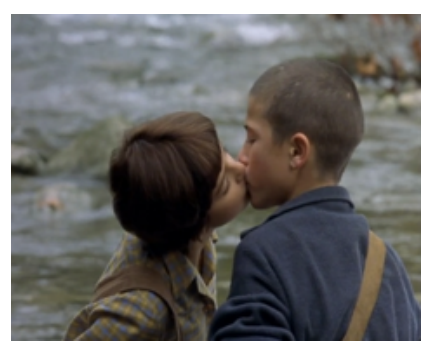

Figure 3

Unlike in El espíritu de la colmena, where the damage wrought by the war on a political and personal level seethes under the surface in every scene, the political sphere in the later films feels cherry-picked and convenient, with archetypical characters standing in for entire sectors of society and giving simplified sound bite explanations of their allegiances and motivations. Likewise, in a frequent move of Memory Boom texts and films, both La lengua de las mariposas and El viaje de Carol also structure the child character's adventures against the backdrop of pivotal political ideas or historical events. ${ }^{14}$ Don Gregorio at one point gives Moncho and his classmates a rousing speech on the children's right to education under the soon-to-be-attacked Second Republic, for example, and just as Carol is about to receive the host at her first communion (where she has 
improbably been permitted to dress in the traditional boy's sailor suit), the ceremony is interrupted by supporters of the military uprising bursting into the church to announce that they have won the war. In a moment of misplaced comic relief intended to show that the Republic's liberalism has come to an end, the priest desists in his half-hearted attempt to give Carol the communion wafer, shaking his head "no" at her as she holds out her tongue in expectation.

What little the films do attempt to engage with the political sphere, however, gives rise to one of the most prominent manifestations of their instrumentalizing approach to the child: the way that both triangulate political binaries through the young protagonist in a forced, oversimplified didacticism of both child and viewer. One such scene occurs in La lengua de las mariposas when Moncho suffers an asthma attack while on a botanical excursion, leading his teacher to plunge him into a cold river to shock him into breathing. Back at Moncho's home, his conservative, religious mother (Uxía Blanco) explains to Don Gregorio that the other time he was saved from such an attack was at his first communion, where splashing his face with holy water revived him in miraculous fashion. The father (Gonzalo Uriarte), a believer in the ideals of the liberal Republic and possible atheist, quips sardonically that the river water was not blessed and still had the same effect. The two parents thus neatly denote opposing positions, simplified and binarized for both child and viewer's didactic benefit. It is perhaps this tendency to provide such neatly packaged political lessons that has made the film so popular in the Spanish language and culture classroom, as it enables an easy summary of a complex historical reality.

Likewise, throughout El viaje de Carol, the film juxtaposes the charismatic, liberal, Americanized mother - who smokes in public and is married to an American fighting in the International Brigades - with the dour, conservative (and winkingly named) aunt Dolores (Lucina Gil), who supports the Nationalist side and has married Adrián (Carmelo Gómez), the man Carol's mother left behind and who evidently still pines for her. In a scene where Dolores chastises Carol for misbehavior, costume choices serve to further visually differentiate the two sisters: in contrast to the recently-deceased mother's sunny disposition and elegant modern dress, Dolores is clad in traditional mourning clothes and wears a severe hairstyle and a prominent crucifix [Figures 4 and 5]. After Dolores notes spitefully that in her willful disobedience Carol takes after her free-spirit mother ("en eso has salido a tu madre"), Carol retorts that she would rather resemble her mother than her aunt; the wounded Dolores replies with a predictable and superficial political barb, telling Carol to change out of her pants as they make her look like a miliciana. 


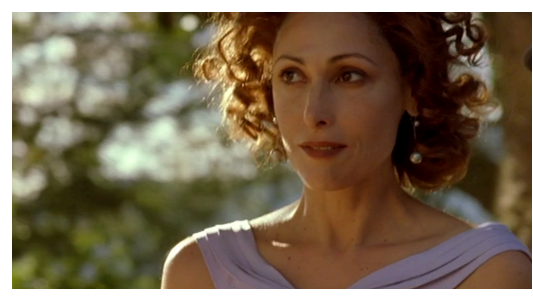

Figure 4

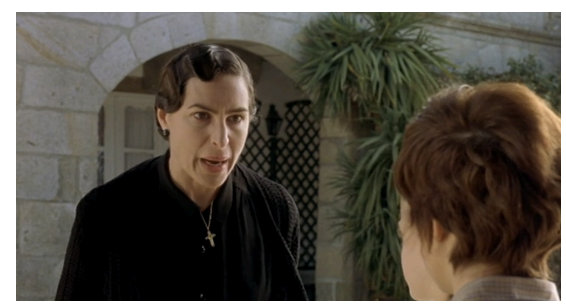

Figure 5

In place of the kind of subjective complexity and opacity that characterized the child protagonist in the intertextual predecessor El espíritu de la colmena, these more contemporary films use their protagonists as vehicles for trafficking in Manichaeism. In these treatments of the historical past, the child is employed to facilitate an easy and oversimplified telegraphing of capital H History, its momentous occasions neatly worked into the coming-of-age tales that the films also tell, explaining complex historical realities through oversimplified caricature. This rather heavy-handed polarization of the adults' comments and actions renders the child a figure enabling binary encounters, in which characters from each side relay to the viewer their political beliefs or allegiances via the child as didactic object.

THE SENTIMENTAL CHILD

In addition to positioning the protagonist as a kind of instructive prism, the two films also cast the child as more object than subject in their recourse to sentimentality and nostalgia - their primary narrative and aesthetic modes. In this the two films are by no means sole offenders; at this point in Spanish heritage cinema, the child's status as indexical of nostalgia, innocent victimhood, and the antediluvian halcyon days is firmly established. Nostalgia in the films aligns with both Susan Stewart's definition of "a longing that of necessity is inauthentic" for a past that one 
has never experienced except as narrative, and with Svetlana Boym's conception of restorative nostalgia, in which "the past is not a duration but a perfect snapshot. Moreover, the past is not supposed to reveal any signs of decay; it has to be freshly painted in its 'original image' and remain eternally young" (Stewart 23; Boym 49). Critics have read the films' recourse to the nostalgia mode with varying degrees of optimism, which I will briefly summarize before addressing the connections between nostalgia and the child. Jordan Tronsgard points out that, generally speaking, nostalgic representations include two aspects: idealization of the event or period in question (in this case, the Second Republic) and the involvement of the present with that past (228). For Tronsgard it is also essential to note that the period memorialized in La lengua de las mariposas is not one that the contemporary spectator or filmmaker has lived through, and therefore "nostalgia for the Republic is largely a collective enterprise" implicating society at large and forging connections to the past, albeit at times problematic ones that may not invite adequate critical reflection (236). ${ }^{15}$ Drawing from Susan Martin-Márquez's analysis of "Second Republic Prelapsarianism" in the "Spanish nostalgia industry," Tronsgard asserts that the Republic itself has taken on an idealized status wrought out of "antifascist impetus and the seemingly parallel desires of present-day democratic Spanish society" (Martin-Márquez 745 and 746; Tronsgard 227).

Jo Labanyi has written in a seminal article on the recurrent tendencies in Memory Boom cultural production toward meticulous historical reconstruction, in contrast to earlier appeals to more disturbing and less realist tropes such as haunting, which more productively "requires the present to correct the past at the same time that it establishes an affective link with it" (II3). While she does not discuss Cuerda's and Uribe's films at length, Labanyi notes that they "adopt a heritage-movie style in order to represent the civil war as a tale of lost community;" we can certainly classify these two films in Labanyi's category of works whose hyperdetailed period aesthetic and historical reconstruction end up paradoxically leading the spectator to feel the present's difference from the past, thus providing the viewer with a sense of moral superiority and distance from the events depicted onscreen (IO3). Antonio Gómez LópezQuiñones adds another level to the nostalgic impulse, noting that in Cuerda's film "nostalgia is not only a tone, a texture, or a visual style, but also a narrative form" created through the film's episodic structure, where the narrative logic stems from Moncho stumbling upon various scenes or situations ("Nostalgia and/as loose causality" III). In his view, La lengua de las mariposas creates nostalgia for the simpler days of rural life in contrast 
to the present-day late-capitalist metropolis that has supplanted it ("Nostalgia and/as loose causality"). Elsewhere, he notes that both the films align the end of childhood with the end of the Second Republic, which is itself presented as a kind of pure, hopeful political infancy, thus problematically metaphorizing childhood as a symbol of the halcyon days before the war (La guerra persistente 219).

Childhood is thus unquestionably central to the films' construction of the past, employed to trigger not just nostalgia for the particular - a yearning for the supposedly simpler times of rural pre-Civil War Spain or the idealized Second Republic - but also the universal: adult longings for a return to childhood innocence and youthful discovery. That is, the reified, innocent prelapsarian time toward which the films nostalgically gesture is not just a particular moment in Spain's pre-war historical past but also the more generally idealized time of childhood itself. In this the films tap into a prevailing impulse in representations of childhood that runs far beyond the Spanish context: the nostalgic linking of the (innocent) child and the (romanticized) past. Anne Higonnet has shown that the child is always a referent for the past of adults, "a past that, being so distinct, so sheltered, so innocent, is also inevitably a lost past, and therefore understood through the kind of memory we call nostalgia" (27). Writing in the context of the British heritage industry, though equally applicable here, Joe Moran has noted the pervasive presence of nostalgia for childhood in contemporary culture, which can take both personal and political forms, as "myths of childhood innocence have often been mobilized [into a soft focus heritage version of the national past] in order to valorize a more 'innocent' national past" (157).

However, the co-opting and entwining of the past and the child by heritage films is founded on a double illusion: that of access to the "real" historical past and to the "real" child, when in fact both these objects of nostalgia are by definition out of reach. Linda Hutcheon notes that nostalgia "may depend precisely on the irrecoverable nature of the past for its emotional impact and appeal. It is the very pastness of the past, its inaccessibility, that likely accounts for a large part of nostalgia's power." Hutcheon goes on to note that the past that emerges through nostalgic recourse is an imagined, idealized past rather than an experiential or recalled one; hence nostalgia has much more to do with the desires of the present than the realities of the past. Or, as Susan Stewart puts it, "This point of desire which the nostalgic seeks is in fact the absence that is the very generating mechanism of desire" (23). The representations of childhood in these two films render the child figure likewise inaccessible, idealized, and imagined; their construction of child characters is less 
concerned with the (nostalgia object) child protagonists of the films than with the (nostalgia consuming) adult spectators who watch them - who with few exceptions are unlikely to possess lived experience of the events depicted. The lost past and the lost child (self) thus both generate nostalgia by their very absence. In this sense the child becomes what Linda M. Austin calls, in the context of British Romantic poetry, a "memorative object to watch and in this way possess without giving up one's position (in every sense of the word) in the present time and place" (97).

It is not just the films' deployment of the child within a general heritage matrix that renders the child this kind of idealized "memorative object" as opposed to agent or subject. On a concrete formal level, especially through camerawork but also music and mise-en-scène, $L a$ lengua de las mariposas and El viaje de Carol construct an objectified vision of childhood, filtered through sentimentality and nostalgia, which denies the child agency or subjective complexity. Noël Carroll has written that in certain fictional films "the detection work that our emotions need to do for us is somewhat minimized because the scenes and characters in such films have very frequently already... been emotively prefocused or predigested for us" (30). Several aspects of the films seek to elicit this kind of prefabricated emotional response, including their golden-hued color scheme and swelling and emotive non-diegetic music played in pivotal moments, but none to the same degree as the embodied child protagonist him or herself. ${ }^{16}$

In both films, the child is frequently deployed as yet another tool in the films' arsenal for evoking sentiment in the spectator, with frequent shots emphasizing his or her emotional expressivity, "innocent" face, or physical vulnerability. In keeping with the films' heritage aesthetics, these images seek to elicit a particular spectatorial response, but as a result do little to represent the child's full subjective complexity. For example, despite thematically focusing to a large extent on Moncho's experiences of learning and discovery, it is significant that La lengua de las mariposas is strikingly devoid of shots filmed from the child character's perspective, or that stress his sensory perception, two key means of approximating the viewer to the child onscreen pointed out by Emma Wilson ("Children, Emotion and Viewing"). Wilson has noted the importance of showing the child's perspective, rather than just what he or she looks like, as a means of approximating the spectator to the child's subjective experience instead of "fix[ing]...represented children as images of childhood innocence," as these films consistently do ("Children, Emotion and Viewing" 340). In visual terms, Moncho is formally constructed as the object of the viewer's gaze, a position he occupies far more than any other in the film, as the camera 
lingers on his emotive face or diminutive stature and few reverse shots represent his subjective viewpoint. El viaje de Carol fares somewhat better in this respect, using shot/reverse shot sequences to show Carol's perspective, especially in repeated lyrical and sensorial shots of her gazing up at the canopy of foliage rustling in the wind [Figures 6 and 7 ].

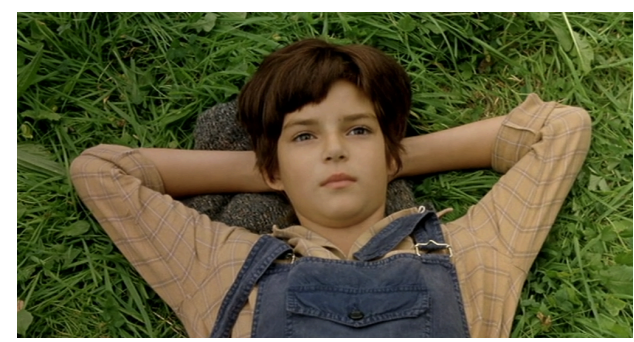

Figure 6

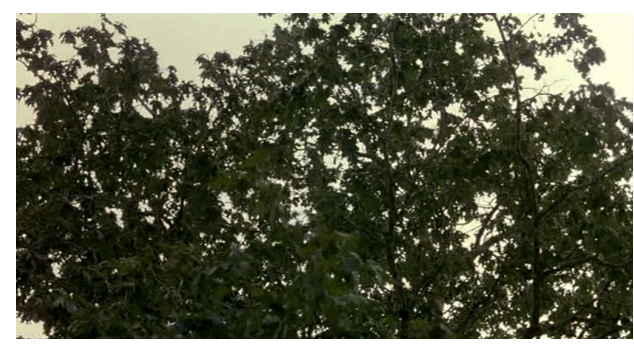

Figure 7

This perspective, however, largely gets lost as yet another piece of the film's meticulously constructed heritage aesthetic. As Faulkner notes, "the beauty of this mise-en-scène leads to the static contemplation of spectacle, rather than dynamic investigation of change" rendering the child Carol part of the "golden-hued nostalgia" that for Alberto Mira characterizes the first sentimental child cinema of Marisol, Joselito, and other child stars (256). ${ }^{17}$ "Rather than treat the child as a subject with whom audiences might identify as a witness to key events," Faulkner writes after Mira, "in this first tradition [of cine con niño], we recall, the child is treated as a "spectacular object'" (256). Unlike the "spectacular object" children described by Mira (singing and dancing sensations like Joselito and Marisol as well as the children of cine religioso like Pablito Calvo of Marcelino, pan y vino) Carol and Moncho could perhaps best be described as "sentimental objects" of the viewer's gaze, serving a parallel function in manipulating 
the viewer's emotions via sentiment rather than spectacle.$^{18}$ Addressing the child's sentimental function in the two films, Gómez López-Quiñones notes that nothing is more obvious and public than their emotions, displayed in close-up on their frequently-filmed faces: "Sus rostros se convierten, de hecho, en un teatro abierto y visible de conflictos, esperanzas, y miedos... El espectador, en vez de reaccionar, es invitado por el montaje de estos filmes a co-reaccionar con los personajes infantiles y sus rostros, que cuentan y expresan traslúcidamente la intensidad y el significado de un determinado conflicto dramático" (La guerra persistente 222).

Yet despite the optimism of this reading, to me there seems to be little of co-feeling in the films, whose sentimental object children exist to elicit an emotional response in the spectator rather than inviting the viewer to contemplate the child's emotional reality. That is, the child's feelings become a sort of transparent lens that allows her emotions to shine through and move the spectator to feel for her more than with her. Near the end of El viaje de Carol, following a clichéd Manichaean chase sequence where the local Falange honcho and Carol's uncle pursue her heroic father, Carol's friend Tomiche is shot as he helps the father escape. "We see alongside and behind Carol in a shot from her eye-level as her father pulls Tomiche from the water, and then in the reverse shot a close up of her tearful face as she watches her father carry her friend's lifeless body toward her" [Figures 8 and 9].

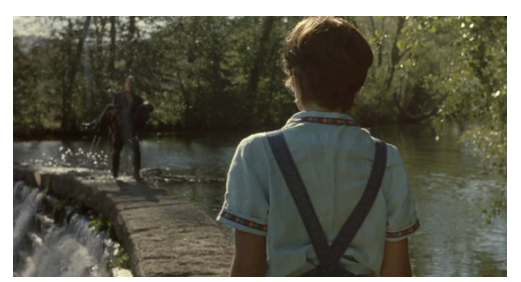

Figure 8

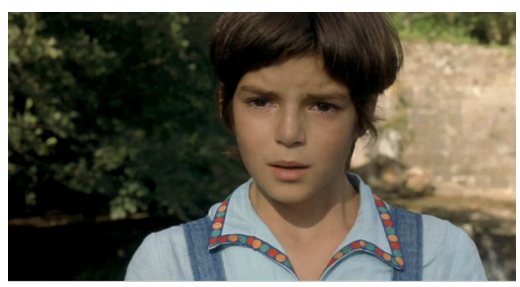

Figure 9 
In contrast to the previous sequence, which showed Carol run and call out to save her father's life, the reverse shot close up casts her as sentimental object rather than active agent, inviting contemplation of her heightened emotional response in the face of Tomiche's unjust death. Carol thus becomes an object of pathos, not unlike her friend, whose lifeless body demands the spectator lament his tragic demise. Rather than instigating feeling with the child as subject, this scene might better be described as inspiring feeling thanks to or on behalf of the child as inert sentimental object. In this sense we might read the sequence along the terms set out by Karen Lury regarding the spectator's emotional response to the child in film:

Tears and emotion erupt when the innocent - dumb animals, little children - are seen to suffer ... Animals and children are "perfect victims," since they are blameless, they make the wrongs of war seem all the more wrong, and the viewer's righteous and explosive response all the more satisfactory. Satisfactory because morally it seems uncomplicated ... and because it puts the viewer in a superior position. (105)

It is toward this position that both films guide the spectator, seeking emotional response and sympathetic alignment with the child onscreen but doing so by offering an oversimplified, transparent reading of the child's subject position. In this sequence from El viaje de Carol (and many others like it in both films), the child character, used as a transparent emotional lens, distils and simplifies what Lury terms "the wrongs of war," enabling or instigating "the viewer's righteous and explosive" emotional response from a comfortable remove. Not unlike the effect that Labanyi describes as emerging from obsessive verisimilitude in filmic reconstructions of the historical past, the child instrumentalized as a kind of sentimental magnifying glass also engenders "the effect of reinforcing the difference of the past from the present, with the result that, at the end of the viewing or reading process, we feel a sense of relief on returning to a present free from such barbarism" (Labanyi I03). The child is perhaps the most powerful tool in this comfortable reification of the past's difference from the present: Carol's tears may momentarily elicit righteous anger at the ruthless Falangist who kills her innocent friend, moving the spectator to moral outrage at the wrongs of war. Immediately thereafter, however, the film glosses over her experience of loss, moving swiftly to its almost happy ending where she imagines a re-animated Tomiche riding his bicycle behind the taxi that spirits her out of town. As the child is shuttled 
back to safety outside Spain's borders, the film likewise allows the spectator to return to the comfort of the present, where the war's senseless violence is a thing of the past.

THE LEGIBLE CHILD

Whether filtered through nostalgic aesthetics, didactic plot devices, or cinematographic frameworks that objectify the child, both films pre-digest for the spectator what the protagonist feels and thinks, leaving little room for the ambiguity that characterizes the child's position in their intertextual precursor, El espíritu de la colmena. In the earlier film, the child's thoughts, feelings, and comprehension of the world around her are left deliberately opaque, as is evidenced by the plethora of critical interpretations of what Ana might be thinking or feeling at particular moments. I would like to propose that it is precisely the absence of such ambiguity that makes these more recent offerings' sentimental approach fall flat; on some level the films, and especially their child protagonists, are too legible, their child characters too easy for spectators to understand or connect with in comfortable nostalgic alignment. It bears noting in this respect that the scene of La lengua de las mariposas that has elicited the most critical attention is its ambiguous conclusion, a still from which serves as the promotional image of the film [Figure Io]. ${ }^{19}$

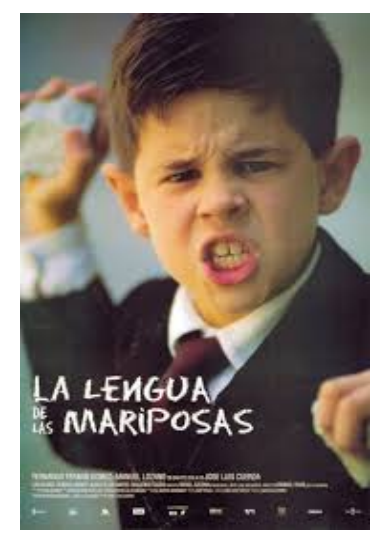

Figure IO

In this scene, which meaningfully overlays the end of the Republic and the end of Moncho's childhood (Gómez López-Quiñones, La guerra persistente), teacher Don Gregorio is carted away for his left-wing sympathies after the outbreak of the war in July i936. Moncho runs after the truck carrying his beloved teacher away, the child's face contorted as 
he hurls stones with other boys and shouts first political epithets and then the scientific words associated with butterflies that his teacher had taught him in simpler days before the outbreak of the war. The scene has provoked the most varied interpretations of any in the film, as critics have alternately read it as demonstrating Moncho's loss of innocence and indoctrination into hatred, or a subtly coded subversion of ideological structures in favor of affective ties. ${ }^{20}$

The wealth of critical attention to this moment in contrast to any other in the film speaks to the possibilities offered by representing the child as less of an open book than the films tend to do. However, this ambiguous representation of the child's subjective reality - the impossibility of understanding exactly what Moncho's thoughts, feelings, or motivations are in this moment, which stands in contrast to the bulk of the film's scenes - is not merely generative in offering a range of critical interpretations. Rather, it also points to the epistemological possibilities of opacity for casting the child as a subject rather than an object. Drawing from Judith Butler's work in Giving an Account of Oneself, Emma Wilson has demonstrated how precisely the representation of the (child) other's unknowability can provide a means of acknowledging her difference in ethical terms, inviting reflection on what it means to know the other: "our opacity to ourselves," Wilson writes, "may be a space for opening to more ethical relations to others, relations which are ethical because they acknowledge hesitancy, lack of knowledge, incompleteness" ("Precarious Lives" 75$).{ }^{2 \mathrm{I}}$ While it is fundamental to acknowledge that the ambiguity or inscrutability of a child character such as Ana in El espíritu de la colmena runs its own risks of projection or instrumentalization, I would nonetheless like to suggest that this earlier film approaches the child character in such a way as to invite reflection on her experience or subjectivity, rather than handing it to the viewer as an open book. In contrast, the clear legibility of the child characters in these more recent films, stemming in large part from their production outside the constraints of censorship and their appeal to the nostalgia mode, not only distances viewers from the historical past the films seek to represent, but also from the child's subjective reality.

Despite the later films' debt to El espíritu de la colmena, there are obvious differences between them, not just in terms of their contexts of production (thirty-four years after the war's end but still in dictatorship in the first case; well into the democratic period and long after the war in the second), but also the historical periods they portray. These newer films, set just before the war or while it is still ongoing, can cultivate nostalgia for all that was lost in its wake, for the unrealized potential of the Second 
Republic's virtual history that was never able to be written. Their intertextual forebear, on the other hand, is set precisely in the immediate postwar moment of devastation and loss, and made in a moment where such loss still had no public outlet and celebration of the Second Republic was impossible. Erice's film could be seen in this sense as a grim aftermath portrait that contrasts starkly in its subject matter and aesthetics with the newer offerings' nostalgic prelapsarian approaches. If El espíritu de la colmena is indeed the foundational film in the "child and the Spanish Civil War" genre, it is crucial to note that its diegetic temporal positioning in relation to that war, not to mention its context of production under dictatorship, necessarily affords a much less rosy picture than the later films set in the last days of the Republic and made under constitutional democracy in the Memory Boom years around the turn of the millennium.

By the same token, the very specific moment and conditions from which Cuerda's and Uribe's films emerge could in large part account for their sentimental and nostalgic frame, especially in contrast to the more complex, darker child-centered films that unequivocally share their status as heirs of El espíritu de la colmena, and which were produced just a few years farther into the Memory Boom period: Guillermo del Toro's El laberinto del fauno (2006) and Agustí Villaronga's Pa negre (2010). ${ }^{22}$ These latter films serve as a kind of photographic negative opposed to the golden nostalgia of La lengua de las mariposas and El viaje de Carol, both in their aesthetics and the darker points of their plots, which find the child protagonist either dying at the hands of a Francoist agent (El laberinto del fauno) or betraying his Republican family and becoming indoctrinated into National Catholicism (Pa negre). Although El laberinto del fauno could be seen to traffic in a kind of Manicheism given its fairy-tale frame structure, Pa negre resolutely upends clear ideas of good and evil and complicates the nostalgic recuperation of Republicanism. That these "golden films" of 1999 and 2002 gave way to increasingly complex and darker inheritors of Erice in 2006 and 2010 could perhaps in part be explained by the first pair's production during the years of José María Aznar of the Partido Popular's tenure as prime minister (1996-2004) and prior to the passage of the 2007 Historical Memory Law. El laberinto del fauno and Pa negre, on the other hand, emerged in the period of José Luis Rodríguez Zapatero's Socialist government, which better fostered critical debates on Spain's contested and violent past and sponsored the passage of the law. Pa negre, the darkest and most complex of the recent "child and the Spanish Civil War" films, also emerged in the wake of another devastating event for Spain: the Global Financial Crisis of 2007-2008 onward. ${ }^{23}$ 
Perhaps as a result of these differences, it seems that the early Memory Boom films want something different from the child in their representation of his or her experience and perspective. In contrast to their iconic predecessor, whose portrayal of protagonist Ana leaves much of her subjectivity opaque for the viewer, despite focusing on her material and emotional experience, Cuerda's and Uribe's films align with André Bazin's conceptualization of "anthropomorphism" in films featuring child protagonists: a process in which the adult spectator or director projects adult meanings or understanding onto the child rather than attempting to show the child's own subjectivity or reality. He writes that with few exceptions, child-centered films "fully play on the ambiguity of our interest in these miniature human beings. Come to think of it, [child-centered] films treat childhood precisely as if it were open to our understanding and empathy; they are made in the name of anthropomorphism" (Bazin I2I). Despite sharing recognizable elements of the "child and the Spanish Civil War" genre with El espíritu de la colmena, these two nostalgia films fall prey to such anthropomorphism in constructing their child characters as emotional prisms or "teatros abiertos," to use Gómez López-Quiñones's term once more. In so doing, they render their protagonists pre-focused, overly-legible, sentimental objects in a disservice to the child, the viewer, and the past.

\section{Brown University}

\section{NOTES}

I This "hot topic" status is due in part to the emergence of the discipline of Childhood Studies; what has been called the "Affective Turn" in cultural and film studies; and to the broad interest in the representation of children on screen that has been kindled in the last years across national boundaries. In the case of Spain's cinema, Lorraine Ryan notes that “Children's prominence in these films can be ascribed to the counter hegemonic tendency of el boom de la memoria, which co-opts the constituent elements of the Francoist regime, such as the family and the child, into their artistic endeavors and imbues them with a subversive signification" (450).

2 As Sally Faulkner notes, the child's importance in Spanish cinema more broadly is evidenced by the fact that the child-centered film genre has a name, "cine con niño," which refers to child-centered films of the I95os featuring key stars such as Marisol and Joselito (252). Erin K. Hogan has categorized a nuevo 
cine con niño composed by the films of late Francoism and the democratic period, noting an increase in their prevalence since the i99os.

3 For more on the Spanish Memory Boom, which is widely documented, see Boyd, Herrmann, and Labanyi, among others.

4 Here I adapt Harold Bloom's widely known term, the "anxiety of influence," from his 1973 The Anxiety of Influence: A Theory of Modern Poetry, which demonstrates how poets struggle with the legacies of their forebears and often produce derivative and weaker versions of the works they admire.

5 This kind of negative comparison is most frequent in studies placing El espíritu de la colmena alongside the two sentimental heritage films I discuss here, as opposed to the films mentioned in the following note, which garner more positive critical comparisons, due to their complexity in representing the child. They are therefore beyond the focus of the present study, though I will return to them at its conclusion.

6 It is worth noting, however, that there is more deep and nuanced critical work comparing Erice's film to three key inheritors that are significantly less sentimental and much darker than the two I explore: Montxo Armendáriz's film Secretos del corazón (1997), which is not set in the Civil War period but the Francoist 1960s, and Mexican-Spanish co-production El laberinto del fauno (Guillermo del Toro, 2006), and Pa negre (Agustí Villaronga, 20IO), both of which are set in the immediate aftermath of the war like El espíritu de la colmena. I would not classify these three films as deploying the same heritage aesthetics or sentimentality as the films I discuss here, although I agree with Sarah Wright, who notes that Secretos del corazón "enjoys a nostalgia for the aesthetics of Francoism" (Io8). In addition to Wright, see, for example: Alvarez-Sancho and Hogan, who trace the "phantom intertexts" linking El espíritu de la colmena to El laberinto del fauno (Alvarez-Sancho), Pa negre and Armendáriz's Secretos del corazón (Hogan); Ballesteros who compares the child's perspective in Erice's two films with Lazcano's 1992 Los años oscuros; Gavela Ramos who argues that the child's gaze in El espíritu de la colmena and El laberinto del fauno generates meaning, as both are "textos que mediatizan el recordar colectivo de la posguerra española" (I84); Miles, who notes via Paul Julian Smith the "clear homage" del Toro pays to Erice in El laberinto del fauno; Pereira Zazo who close reads Erice's and Armendáriz's films' use of focalization to problematize existing readings of the former and argue for the more nuanced ambiguity of Ana's perspective in El espíritu de la colmena in contrast to the more camera-aligned perspective of protagonist Javi in Secretos del corazón; Ruhe who considers both Erice's Ana and Ofelia in El laberinto del fauno as "portadoras de la(s) historia(s)" (57) and notes the films' strong intertextual connections; Stone whose chapter "Spirits and Secrets: Four Films about Childhood" analyzes El espíritu de la colmena alongside Erice’s El sur, 
Saura's Cría cuervos and Secretos del corazón to note how "the natural wonderment of childhood was transformed into a distressful fear of the unknown and the unknowable: a parent's past and a child's own future (85)" or Zumalde Arregi who in arguing for a more complex definition of national cinema contends that El laberinto del fauno is "una reproducción a contrario de El espíritu de la colmena" in del Toro's inversion of several of Erice's plot points and themes, which he details in a useful schematic list (200-20I).

7 While neither of the contemporary films with which this article concerns itself fall within the horror genre, Sarah Wright has noted that El espíritu de la colmena can be seen to have instigated a genre she terms "art-house horror," where the child has a frequent presence. I have written elsewhere ("Ghostly Affinities" and "Phantom Children") of the privileged connection of the child and the ghost in Spanish cinema, especially cinema dealing with Spain's contested and violent past. See also Pramaggiore on the child as a temporally complex figure in Spanish horror films.

8 To name just a few of the films that link childhood and the Spanish Civil War, many of which are analyzed by Wright, we could include: Los años oscuros (Urte ilunak, Lazcano, 1992); Las bicicletas son para el verano (Chávarri, 1984), En el balcón vacío (García Ascot, 1962), El espinazo del diablo (del Toro, 2001); La guerra de papá (Mercero, 1977), El jardín de las delicias (Saura, 1970); Los girasoles ciegos (Cuerda, 2008); El laberinto del fauno (del Toro, 2006); Pa negre (Villaronga, 2010); La prima Angélica (Saura, 1974); Secretos del corazón (Armendáriz, 1997); El sur (Erice, 1983), among others.

9 According to the Ministerio de Educación, Cultura y Deporte, La lengua de las mariposas was the fifth-highest-grossing domestic film of 1999 with 918,569 spectators and a box office of $€_{3}, 678,048$. El viaje de Carol does not make the top ten in 2002. See: http://www.mecd.gob.es/culturamecd/en/dms/mecd/cultura-mecd/areas-cultura/cine/informacionservicios/in/informes-publicaciones/EvolucCineEspı996-2003.pdf

Io Colmeiro notes that the film "moviliza los clichés del maestro machadiano, el cura retrógrado, y el cacique parafascista" (193); and even Uribe himself in an interview has admitted the "archetypal" nature of his characters (Aguirresarobe).

II While the most evident and frequently commented intertext in each is $E I$ espíritu de la colmena, we can also find traces of other auteur films such as Saura's El jardín de las delicias (I970) - for example the scene in which Carol's communion is interrupted by the Rebel victory in the Civil War, much like $E l$ jardín de las delicias's protagonist's by the declaration of the Republic - or Erice's El sur (1983), in the repeated use in La lengua de las mariposas of the tune En er mundo and El viaje de Carol's opening sequence set on a train. Other El espíritu de la colmena cues include the schoolroom scenes in La lengua de 
las mariposas, and the family in El viaje de Carol singing the children's song "Vamos a contar mentiras," a vital part of El espíritu de la colmena's soundtrack.

While beyond the scope of the present article to analyze in detail, it is worth noting that the gender identity and age of the protagonists in the more recent films set them apart from Erice's: where Ana was a young girl of about six, Moncho is a boy of closer to ten, and Carol an adolescent girl of twelve who is strongly coded as a tomboy; both these subject positions would appear less marginal than the very young girl's. This may be in part because the latter films do not engage in the same kind of radical anti-hegemonic critique of the adult world that Isolina Ballesteros reads in their predecessor's focus on young Ana: "Representar la realidad de los años oscuros de la posguerra desde los ojos de una niña es un acto político, es renunciar a la mirada adulta hegemónica, al estado de dominación, al cuerpo político masculino, para dar la autonomía al cuerpo infantil, todavía sin órganos, símbolo del 'devenir-joven' de cada edad y concentrarse en el proceso del devenir mismo" (233).

I3 This and other images from El viaje de Carol are reproduced with generous permission from Film Movement.

I4 Gómez López-Quiñones has outlined the ways in which the child's (lost) innocence often stands in for the nation's in recent films dealing with the Spanish Civil War, where "childhood overlaps with a certain national past" which might "function as a sort of collective childhood" ("Fairies, Maquis, and Children" 57). He further notes that "The danger in representing the Spanish Civil War and the subsequent triumph of Francoism as a loss of youth is that of freezing the complexity of a historical process into an archetype. In this, the cultural specificity of the event itself is lost" ("Fairies, Maquis, and Children" 59).

I5 Along these lines Tronsgard also reads La lengua de las mariposas and in particular the function of Don Gregorio via Boym's concept of restorative nostalgia, which "Because it does not recognize itself... lacks ambivalence and self critique" (240). Francis Lough reads the intertext of Machado and association with anarchism as giving Don Gregorio a symbolic role that serves as "an invitation to the audience to condemn but also to look beyond the violence perpetrated by Franco and his Nationalist army.... An important issue in the film, however, is the extent to which such serious comment is undermined by nostalgic discourse" (I63).

I6 Of El viaje de Carol, Sally Faulkner has noted that "Bingen Mendizábal's original score plays a key role in emphasizing the saccharine elements of the visual track" where musical motifs "predictably underscore moments of emotional intensity" which "serve throughout to exaggerate moments that are already highly sentimental" (256-7). Much the same could be said of the score 
in La lengua de las mariposas, where whimsical music plays under the scenes of Moncho's naturalist expeditions with Don Gregorio to suggest the wonder of the child as he discovers the natural world.

I7 Mira casts the "spectacular object" child motif (77) in contrast to the "child witness" motif (78) emblematized by El espíritu de la colmena. Mira, however, positions La lengua de las mariposas in the second group (80).

I8 On this function in early films (of the cine religioso and cine con niño genres), see Wright on the "cute aesthetic" (32ff) drawing from Harvey.

I9 Image courtesy of Miramax.

20 Ryan notes that "[t]his final scene of the film has proved to be theoretically contentious, as some theorists alternatively interpret it as the triumph of violence and the end of Moncho's childhood, while others consider it a coded message of complicity" (448). Analyses of this sequence abound in critical literature, often centrally to whatever argument is made regarding the child's role in the film.

2I Wilson notes, following Judith Butler's 2005 Giving an Account of Oneself, that "trouble in subject formation, our opacity to ourselves, may be a space for opening to more ethical relations to others, relations which are ethical because they acknowledge hesitancy, lack of knowledge, incompleteness. I suggest that these films showing girl subjects, their vulnerabilities, their escape from fixity, the intermittencies of their lives, reflect on what it is to be a subject and what it can be to know, or not know, the other" (75).

22 On the intertextual connections between El espíritu de la colmena and these two films, see note number 6 .

23 The Aznar years also saw a policy of film subventions based on commercial success, which could in part account for Cuerda's and Uribe's films' golden aesthetics and simplified historical content, the latter of which also marks El laberinto del fauno, a blockbuster international co-production like La lengua de las mariposas (co-produced by France's Sogetel and Canal + Spain) that sought (and found) success at the foreign box office. I would like to thank one of the anonymous reviewers for pointing toward the importance of the films' production in the Aznar years (among other useful comments for the revision of this article).

\section{WORKS CITED}

A G U I R R E S A O B E, J A VIE R. Luces y sombras en el cine de Imanol Uribe. Valladolid:

Semana Internacional de Cine de Valladolid, 2004. 
ALVAREZ-SANCH O, ISABEL. "Pa negre y los otros fantasmas de la postmemoria: El 'phantom' y los intertextos con La plaça del Diamant, El espíritu de la colmena y El laberinto del fauno." MLN I31.2 (2016): 517-535.

A USTIN, Lind A M. "Children of Childhood: Nostalgia and the Romantic Legacy." Studies in Romanticism 42.I (2003): 75-98.

B ALlester os, is olina. "Las niñas del cine español: La evasión infantil en $E l$ espíritu de la colmena, El sur, y Los años oscuros." Revista Hispánica Moderna 49.2 (1996): 232-242.

BAZIN, AN D RÉ. Bazin at Work: Major Essays \& Reviews from the Forties \& Fifties. Trans. Alain Piette and Bert Cardullo. Ed. Bert Cardullo. New York: Routledge, 1997.

B L O O M, HAR L D. The Anxiety of Influence: A Theory of Modern Poetry. Oxford: Oxford UP, I997.

B O D, CAROLYN P. "The Politics of History and Memory in Democratic Spain." The Annals of the American Academy of Political and Social Science 617 (2008): 13348.

в о ум, SVE TLAna. The Future of Nostalgia. New York: Basic Books, $200 \mathrm{I}$.

CARr OLl, Nö̈L. "Film, Emotion, and Genre." Passionate Views: Film, Cognition, and Emotion, Ed. Carl Plantinga and Greg M. Smith. Baltimore: Johns Hopkins UP, I999. $2 \mathrm{I}-47$.

Colmeiro, José F. Memoria histórica e identidad cultural: De la postguerra a la postmodernidad. Barcelona: Anthropos, 2005.

El espíritu de la colmena. Dir. Víctor Erice. Perf. Ana Torrent, Isabel Tellería, Fernando Fernán-Gómez, and Teresa Gimpera. Elías Querejeta Producciones Cinematográficas S.L., Jacel Depósito, 1973. Criterion Collection.

FA L K NE R, SALly. A History of Spanish Film: Cinema and Society 1910-2010. London: Bloomsbury, 2013.

GAVELA RAMOS, YVONNE. "El acto colectivo de recordar: historia y fantasía en $E l$ espíritu de la colmena y El laberinto del fauno." Bulletin of Hispanic Studies 88.2 (2OII): 179-96.

Gómez LóPEZ-QUiñ ONES, ANTONio. "Fairies, Maquis, and Children without Schools: Romantic Childhood and Civil War in Pan's Labyrinth." Representing History, Class, and Gender in Spain and Latin America: Children and Adolescents in Film. Eds. Carolina Rocha and Georgia Seminet. New York: Palgrave Macmillan, 2012. 49-62.

- La guerra persistente. Memoria, violencia y utopía: representaciones contemporáneas de la guerra civil española. Madrid: Iberoamericana/Vervuert, 2006.

—. "Nostalgia and/as loose causality in Belle Époque and La lengua de las mariposas." International Journal of Iberian Studies 27.2 \& 3 (2014): I05-I2O. 
HARVEY, JES SAm Y. "Death and the Adorable Orphan: Marcelino, pan y vino (1954; I99I; 2000)." Journal of Romance Studies 4.I (2004): 63-77.

HERRMAN , GinA. "A Usable Nostalgia for Spain: Oral History and the Novel." Journal of Romance Studies 2.2 (2002): 70-90.

H I G ONNET, AN E. Pictures of Innocence: the History and Crisis of Ideal Childhood. London: Thames and Hudson, 1998.

HOGAN, ERIN K. "Queering Post-War Childhood: Pa negre (Agustí Villaronga, Spain 2010)." Hispanic Research Journal I7.I (2016): I-I8.

HUTCHEON, L INDA. "Irony, Nostalgia, and the Postmodern." University of Toronto English Library (2002). S. pag. Web.

KInDER, MARShA. "The Children of Franco in the New Spanish Cinema." Quarterly Review of Film Studies (Spring 1983): 57-76.

labanyi, Jo. "Memory and Modernity in Democratic Spain: The Difficulty of Coming to Terms with the Spanish Civil War." Poetics Today 28.I (2007): 89II6.

LEB AAU, Vicкy. Childhood and Cinema. London: Reaktion Books, 2008.

La lengua de las mariposas. Dir. José Luis Cuerda. Perf. Fernando Fernán-Gómez, Manuel Lozano. Canal + España, Sogetel, et al., I999. Warner Sogefilms, 2002. L OU G H, F R A C Is. "La lengua de las mariposas: Symbolism and Nostalgia in an Ideological Context." Symbolism 7 (2007): 149-68.

LuRY, KAREN. The Child in Film: Tears, Fears, and Fairy Tales. New Brunswick: Rutgers UP, 2010.

MARTIN-MÁRqUEZ, SUSAN. "Spanish Literature and the Language of New Media:

From Film Adaptation to Digitized Cultural Interfaces." The Cambridge History of Spanish Literature. Ed. David T. Gies. Cambridge: Cambridge UP, 2004. 73955 .

miles, rо веR t J. “Reclaiming Revelation: Pan's Labyrinth and The Spirit of the Beehive." Quarterly Review of Film and Video 28.3 (201I): 195-203.

M IRA, A L B E R T o. The A to $Z$ of Spanish Cinema. Lanham: The Scarecrow Press, 2010. M ORAN, JoE. "Childhood and Nostalgia in Contemporary Culture." European Journal of Cultural Studies 5.2 (2002): 155-173.

M U L LER, ADAM. "Notes toward a Theory of Nostalgia: Childhood and the Evocation of the Past in Two European 'Heritage' Films. New Literary History 37.4 (2006): 739-760.

PEREIRA Zazo, óscar. "Cuestión de puntos de vista: la mirada infantil en El espíritu de la colmena y Secretos del corazón." La cultura mediàtica: Modes de representació i estratègies discursives (Quaderns de Filología. Estudis de Comunicació Vol I). Eds. Josep V. Gavaldà Roca, Carmen Gregori Signes, and Ramon X. Rosselló Ivars. Valencia: Facultat de Filología, Universitat de València, 2002. 227-38. 
PRAMAGGIORE, MARI A. "Suspendido en el tiempo: Children and Contemporary Spanish Horror." Tracing the Borders of Spanish Horror Cinema and Television. Ed. Jorge Marí. New York: Routledge, 2017. 67-87.

RUHE, CORNELIA. "El espíritu en el laberinto. La memoria filosófica de la guerrilla en películas de Víctor Erice y Guillermo del Toro." La memoria cinematográfica de la guerrilla antifranquista. Eds. Pere Joan Tous and Cornelia Ruhe. Foro hispánico 57 (2017): 39-58.

RYAN, LORRAINE. "The Development of Child Subjectivity in La lengua de las mariposas." Hispania 95.3 (2012): 448-60.

smith, paul julian. "Butterfly's Tongue" (review). Sight and Sound ro.9 (2000): 39-40.

ST EWA RT, su SA N. On Longing: Narratives of the Miniature, the Gigantic, the Souvenir, the Collection. Durham: Duke UP, 1992.

ST ONE, Rо B. Spanish Cinema. Harlow: Longman (Pearson Education), 2002. тнома S, SARAн. "Ghostly Affinities: Child Subjectivity and Spectral Presences in El espíritu de la colmena (1973) and El espinazo del diablo (2001)." Hispanet 4 (20II). "The Hispanic Gothic." S. pag. Web.

—. "Phantom Children: Spectral Presences and the Violent Past in Two Films of Contemporary Spain." Espectros: Ghostly Hauntings in Contemporary Transhispanic Narratives. Eds. Alberto Ribas-Casasayas and Amanda L. Petersen. Lewisburg: Bucknell UP, 20ı6. IоI-II6.

TRONSGARD, J ORDAN. "Ironic Nostalgia: The Second Republic Today in Manuel Rivas's El lápiz del carpintero." Anales de la literatura española contemporánea 36.I (2OII): 225-247.

El viaje de Carol. Dir. Imanol Uribe. Perf. Clara Lago, Juan José Ballesta. Film Movement, 2002.

WILSO N, E Mm A. "Children, Emotion and Viewing in Contemporary European Film." Screen 46.3 (2005): 329-340.

—. "Precarious Lives: On Girls in Mia Hansen-Løve and Others." Studies in French Cinemas I2.3 (2012): 273-284.

Wright, sarah. The Child in Spanish Cinema. Manchester: Manchester UP, 2013. ZUmALDE ARREgi, imanol. "El laberíntico caso del Fauno. A propósito de la identidad nacional de las películas." zer: Revista de Estudios de Comunicación I8.34 (2013): 195-209. 